\title{
Profile of Opportunistic Infections and CD4 Count in HIV/AIDS Patients in and Around Vijayapur, Karnataka, India
}

\author{
Sayeda Yasmeen Khadri ${ }^{*}$, Sayed Yunus Khadri ${ }^{2}$, Raveendra D. Totad ${ }^{3}$ and \\ Asma Begaum Biradar ${ }^{1}$
}

\author{
${ }^{1}$ Department of Microbiology, Al-Ameen Medical College, Vijayapur, Karnataka, India \\ ${ }^{2}$ Department of Forensic Medicine and Toxicology, Al-Ameen Medical College, Vijayapur, \\ Karnataka, India \\ ${ }^{3}$ SMO, ART Centre Government District Hospital, Vijayapur, Karnataka, India \\ *Corresponding author
}

\begin{tabular}{|c|c|}
\hline & A B S T R A C T \\
\hline $\begin{array}{l}\text { Ke y w o r d s } \\
\text { Human } \\
\text { immunodeficiency } \\
\text { virus, Opportunistic } \\
\text { infections, CD4 } \\
\text { count, Tuberculosis, } \\
\text { AIDS. }\end{array}$ & $\begin{array}{l}\text { Human immunodeficiency virus (HIV) is responsible for depletion of CD4 cell count. } \\
\text { Thus resulting in the rise of opportunistic infections (OI) leading to increase in morbidity } \\
\text { and mortality in HIV infected patients. The aim of the study was to observe the } \\
\text { opportunistic infections and CD } 4 \text { count in HIV/AIDS patients. The work was done in } \\
\text { Microbiology, Al-Ameen Medical College Vijayapur, Karnataka from January } 2012- \\
\text { December 2012. The relevant investigations were carried out along with CD4 count. } \\
\text { Among total } 1254 \text { HIV patients it was seen males had increase preponderance than } \\
\text { females. Heterosexual route been commonest mode of transmission. Common }\end{array}$ \\
\hline Article I & $\begin{array}{l}\text { opportunistic infections were pulmonary tuberculosis } 44.66 \% \text {, Candidiasis } 23.92 \% \text {, } \\
\text { Cryptosporidial diarrhea } 19.46 \% \text {, Herpes zoster } 3.19 \% \text {, Cryptococcal meningitis } 2.80 \% \text {, }\end{array}$ \\
\hline $\begin{array}{l}\text { Accepted: } \\
\text { 26 July } 2017 \\
\text { Available Online: } \\
10 \text { September } 2017\end{array}$ & $\begin{array}{l}\text { Pneumocystis jiroveci pneumonia } 1.99 \% \text { and other miscellaneous infections } 3.98 \% \text {. } \\
\text { CD4count in } 41.70 \% \text { was between } 201-500 / \mu 1 \text { followed by } 29.10 \% \text { between } 101-200 / \mu 1 \text {. } \\
\text { The present study demonstrates the profile of opportunistic infections and CD4 count in } \\
\text { HIV/AIDS patients. }\end{array}$ \\
\hline
\end{tabular}

\section{Introduction}

As per National AIDS Control Organisation of India, in 2013 prevalence of AIDS was 0.27. (www.ndtv.com.HIV/AIDS). HIV/AIDS has remained as global pandemic with cases being reported from virtually every country. Worldwide the total numbers of cases are 34.2 million (UNAIDS, 2011). Around 3.97 million were reported as cases of HIV infection in India (Sharma et al., 2003). Opportunistic infections are noted complications of Human immunodeficiency virus (HIV) infection leading to high mortality and morbidity (Kaplan et al., 1996; Moore et al., 1996). Prevalence of various infections varies in different areas of the country and also in different countries (Ayyagari et al., 1999).

\section{Objectives}

We conducted this study the profile of OIs and CD4 count in HIV/AIDS patients helping in introduction of prophylaxis and therapeutic measures for patient's betterment. 


\section{Materials and Methods}

Our study was carried out in Al-Ameen Medical College and Government District hospital, Vijayapur, Karnataka India. A total of 1254 HIV positive patients from January 2012 to December were included in the study. Before starting antiretroviral therapy (ART), CD4 count estimation was done at the ART Centre District hospital, Vijayapur.

\section{Exclusion criteria}

Patients reporting with other immunosuppressive disorders, on immunosuppressive therapy and pediatric age group were excluded from the study.

\section{Ethical consideration}

Al-Ameen institutional ethical committee gave ethical clearance for our study. Individual informed consent collected from each patient.

All the HIV positive 1254 patients were subjected to various tests or investigations for detection of opportunistic infections. Their HIV test and CD4 count estimation was done according to NACO guidelines. CD4 count was done using 5-fluorescence-activated cell sorting count flow cytometer (Becton, Dickenson, Sanjose, Calif., USA) (NACO guidelines, 2007). For all the patients ART was started as per NACO guidelines. The opportunistic infections were recorded in these patients. Various samples depending on the system involved were collected with sterile precautions and relevant investigations were done as per the standard guidelines (Bailey and Scott, 2002).

The diagnosis of tuberculosis was made by Ziehl Neelsen stain, chest $\mathrm{x}$-ray and history along with symptoms. The Candida infection infection was diagnosed by Gram stain, $\mathrm{KOH}$, fungal culture was done on SDA and specific tests related to Candida were done to identify the species of candida. Cryptosporidiosis and other parasitic infections were diagnosed by modified Z.N. stain. Viral infections like Herpes simplex and Herpes zoster detected by clinical presentation and Tzanck smear. Fungal infection like Cryptococcal meningitis was identified by India ink preparation, culture on SDA, agglutination test and biopsy. Pneumocystis jiroveci pneumonia cases were confirmed by clinical features, chest x-ray, silver methamine stain and arterial blood gas analysis. Other culture media like blood agar, chocolate agar, Lowenstein Jensen media, MacConkey agar and Sabouraud's dextrose agar were inoculated to grow microbial pathogens.

\section{Results and Discussion}

Out of 1254 HIV patients 683(54.47\%) were males and 571(45.53\%) females. Male patients between age group of 31-40 years were maximum 265(21.13\%). In female patients maximum were in 31-40 years, 235(18.74\%) (Table 1).

Majority of the HIV patients belonged to coolie group both in male and among female patients 900(71.77\%), about 196(15.62\%) were Housewives (Table 2).

The commonest route of transmission was Heterosexual in $1000(79.74 \%)$ followed by $125(9.97 \%)$ spouse being positive, parenteral route $75(5.98 \%)$ respectively. Around $54(4.31 \%)$ the route of transmission was unknown (Table 3 ).

Pulmonary tuberculosis was been noted as commonest opportunistic infection in the study 560(44.66\%), Candidiasis in $300(23.92 \%)$, Cryptosporidial diarrhea in 244(19.46\%), Herpes zoster in 40(3.19\%), Cryptococcal meningitis in $35(2.80 \%)$, 
Pneumocystis jiroveci pneumonia in $25(1.99 \%)$ and other miscellaneous infections accounted in 50(3.98\%) patients (Table 4).

CD4 count being maximum ranging between $201-500 / \mu 1$ in $523(41.70 \%)$ followed by $101-$ $200 / \mu 1$ in $365(29.10 \%), 51-100 / \mu 1$ in $221(17.62 \%), 0-50 / \mu 1$ in $102(8.13 \%)$ and $>500 / \mu \mathrm{l}$ in $43(3.42 \%$ ) (Table 5).

This study was done to observe the opportunistic infections and CD4 count in HIV patients which can help to adopt prophylactic measures to reduce various opportunistic infections.
Our study shows the common age of presentation of patients between 31-40years 500(39.87\%). Moore et al., in 1996 showed $48 \%$ were in the age group between 31 to 40 years. In another study by Praveen R. Shahapur in 2014 showed 31-40 years age group was found to be most commonly (41.66) involved among men.

Most common route of transmission noted was heterosexual route 1000(79.74\%). Gupta in 2007, Praveen R. Shahapur in 2014 and Kumar in 2012 also reported heterosexual route as the commonest route of transmission of HIV infection.

Table.1 Age and Sex distribution

\begin{tabular}{|l|l|l|l|l|l|}
\hline Age & Male $=\mathrm{n}$ & $\%$ & Female=n & $\%$ & Total = \% \\
\hline $1-10$ years & 00 & 00 & 00 & 00 & 00 \\
\hline $11-20$ years & 30 & $2.4 \%$ & 20 & $1.59 \%$ & $3.99 \%$ \\
\hline $21-30$ years & 240 & $19.14 \%$ & 135 & $10.77 \%$ & $29.91 \%$ \\
\hline 31-40years & 265 & $21.13 \%$ & 235 & $18.74 \%$ & $39.87 \%$ \\
\hline 41-50years & 112 & $8.93 \%$ & 120 & $9.57 \%$ & $18.5 \%$ \\
\hline $51-60$ years & 30 & $2.39 \%$ & 50 & $3.99 \%$ & $6.38 \%$ \\
\hline $61-70$ years & 5 & $0.4 \%$ & 10 & $0.79 \%$ & $1.19 \%$ \\
\hline $71-80$ years & 1 & $0.08 \%$ & 1 & $0.08 \%$ & $0.16 \%$ \\
\hline Total & 683 & $54.47 \%$ & 571 & $45.53 \%$ & 100 \\
\hline
\end{tabular}

Table.2 Occupation of the patient

\begin{tabular}{|l|l|l|}
\hline Occupation & Male & Female \\
\hline Agriculture & 77 & 00 \\
\hline Employed & 05 & 00 \\
\hline Business & 26 & 01 \\
\hline Coolie & 527 & 373 \\
\hline Driver & 47 & 01 \\
\hline Housewife & 00 & 196 \\
\hline Others/student & 01 & 00 \\
\hline Total & 683 & 571 \\
\hline
\end{tabular}

Table.3 Mode of transmission

\begin{tabular}{|l|l|l|l|}
\hline Sl.no & Route of transmission & $\mathrm{n}=1254$ & $\%$ \\
\hline 1 & Heterosexual & 1000 & $79.74 \%$ \\
\hline 2 & Spouse being positive & 125 & $9.97 \%$ \\
\hline 3 & Intravenous drug abusers or parenteral route & 75 & $5.98 \%$ \\
\hline 4 & Not known & 54 & $4.31 \%$ \\
\hline
\end{tabular}


Table.4 Opportunistic infections in HIV/AIDS patients

\begin{tabular}{|l|l|c|c|}
\hline Sl.no & Opportunistic infection & $\mathrm{n}=1254$ & $\%$ \\
\hline 1 & Pulmonary tuberculosis & 560 & $44.66 \%$ \\
\hline 2 & Candidiasis & 300 & $23.92 \%$ \\
\hline 3 & Cryptosporidial diarrhea & 244 & $19.46 \%$ \\
\hline 4 & Herpes zoster & 40 & $3.19 \%$ \\
\hline 5 & Cryptococcal meningitis & 35 & $2.80 \%$ \\
\hline 6 & Pneumocystis jiroveci pneumonia & 25 & $1.99 \%$ \\
\hline 7 & Miscellaneous infections & 50 & $3.98 \%$ \\
\hline
\end{tabular}

Table.5 CD4 count in HIV/AIDS patients

\begin{tabular}{|l|l|l|l|}
\hline Sl.no & CD4 count & $\mathrm{n}=1254$ & $\%$ \\
\hline 1 & $0-50$ cells $/ \mu 1$ & 102 & $8.13 \%$ \\
\hline 2 & $51-100$ cells $/ \mu 1$ & 221 & $17.62 \%$ \\
\hline 3 & $101-200$ cells $/ \mu 1$ & 365 & $29.10 \%$ \\
\hline 4 & $201-500$ cells $/ \mu 1$ & 523 & $41.70 \%$ \\
\hline 5 & $>500$ cells $/ \mu 1$ & 43 & $3.42 \%$ \\
\hline
\end{tabular}

Our study showed evidence of pulmonary tuberculosis among 560(44.66\%) of HIV patients followed by Candidiasis 300 (23.92\%), Cryptosporidial diarrhea 244 (19.46\%), Herpes zoster 40 (3.19\%), Cryptococcal meningitis 35 (2.80\%), Pneumocystis jiroveci pneumonia 25 $(1.99 \%)$ and other infections 50 (3.98\%). Kumaraswamy in 1995 also reported commonest opportunistic infections as tuberculosis in $61 \%$, Candidiasis $41 \%$, diarrhea $16 \%$ and fungal infections of skin $16 \%$.

Misra in 1998 observed tuberculosis 62\% incidence, Candidiasis $57 \%$ and chronic diarrhea $47 \%$ among the opportunistic infections.

Sharma SK in 2004 showed tuberculosis to be the commonest opportunistic infections $71 \%$, Candidiasis 39.3\%, Pneumocystis jiroveci pneumonia $7.4 \%$, Cryptococcal meningitis and cerebral toxoplasmosis $3.7 \%$ each.

Vinay KV in 2012 observed tuberculosis in 64\%, Candidiasis 30\%, Pneumocystis jiroveci pneumonia $18 \%$, Herpes infection $12 \%$ and Cryptosporidial diarrhea $10 \%$ and Cryptococcal meningitis $2 \%$ as the common opportunistic infections.

The CD4 count in the study shows following CD4 count between 201-500 cells/ $\mu 1$ was seen among 523(41.70\%), 101-200 cells/ $\mu 1$ in $365(29.10 \%), 51-100$ cells $/ \mu 1$ in $221(17.62 \%)$, $0-50$ cells $/ \mu 1$ in $102(8.13 \%)$ and $>500$ cells $/ \mu 1$ in $43(3.42 \%)$.

Similar findings were reported by Srirangaraj in 2011 and Ravinder Kaur in 2016.

Our conclusion is majority of HIV patients were male among sexually active and working age group. Commonest route of transmission is Heterosexual route of transmission of HIV infection. Tuberculosis and Candidiasis were observed as the maximum cases reported among opportunistic infections. Depletion of CD4 cells results in causing more opportunistic infections. To delay the progression to AIDS, prolong the life span and prevent complication we have to have early diagnosis and adopt prompt measures for treating the opportunistic infections.

\section{Acknowledgement}


I thank Dr. Raveendra totad, SMO ART Centre government district hospital Vijayapur for providing the patients data. All teaching and non-teaching staff for assisting in completion of the study.

\section{References}

Ayyagari, A., et al., 1999. Spectrum of opportunistic infections in human immunodeficiency virus (HIV) infected cases in a tertiary care hospital. Indian $J$ Med Microbiol, 17: 78-80.

Forbes, B.A., Diagnostic microbiology, $11^{\text {th }}$. Ed 2002. Laboratory methods in HIV/AIDS.

Gupta, V., et al., 2007. Clinico-epidemiological profile of HIV infection over a period of six years in a North Indian tertiary care hospital. Indian J Med Microbiol, 25: 171. http://www.ndtv.com/video/player/news/wo rld-aids-days-India-records-sharp-drop-innumber-of-cases/299798.

Kaplan, J.E., et al., 1996. Preventing opportunistic infections in human immunodeficiency virus-infected persons: implications for the developing world, Am J Trop Med Hyg., 55:1-11.

Kumar, S., et al., 2012. Profile of presentation of human immunodeficiency virus infection in North India. Indian J of Comm Med., 37: 158-164.

Kumaraswamy, N., et al., 1995. Spectrum of opportunistic infections among AIDS Patients in Tamilnadu, India. Int $J$ STD AIDS., 6: 447-9.

Misra, S.N., et al., 1998. Recent trends in opportunistic infections. Southeast Asian J Trop med Public Health. 29:373-6

Moore, R.D., et al., 1996. Natural history of opportunistic disease in an $\mathrm{HIV}$-infected urban clinical cohort. Ann Intern med., 124:633-42.
National AIDS Control Organisation. Guidelines for the enumeration of CD4 T-lymphocytes with single platform Technology for initiaton and monitoring of ART in HIV infected individuals. NACO: March 2007.

National AIDS Control Organisation. Guidelines on HIV-Testing. NACO: March 2007.

Praveen R. Shahapur et al., 2014. Recent trends in the spectrum of opportunistic infections in human immunodeficiency virus infected individuals on antiretroviral therapy in South India. J Nat Sc Biol and Med., 5: 392-396.

Ramana, K.V., et al., 2009. Opportunistic intestinal parasites and T CD4 cell count in human immunodeficiency virus seropositive patients. J Med Microbiol, 58: 1664-6.

Ravinder Kaur, et al., 2016. Spectrum of opportunistic fungal infections in HIV/AIDS patients in tertiary care hospital in India. Can J Infect Dis Med Microbiol, 2373424 ?

Sharma, S.K., et al., 2004. Spectrum of clinical disease in a series of 135 hospitalised HIVinfected patients from North India. BMC Infect Dis., 4: 52.

Sharma, V.K., 2003. Sexually transmitted diseases and AIDS, New Delhi: Viva Books Pvt Ltd, 59-129.

Srirangaraj, S., et al., 2011. Opportunistic infections in relation to antiretroviral status among AIDS Patients from South India. Indian J Med Microbiol, 29(4): 395-400.

UNAIDS, 2011. Available: http://search 2.unaids.org/custom/search.asp.

Vinay, K.V., et al., 2012. Study of the relationship between CD4 count and clinical features I HIV-infected patients in South Indian population. Indian Journal of Fundamental and Applied Life Sciences, 2(3):153-161.

\section{How to cite this article:}

Sayeda Yasmeen Khadri, Sayed Yunus Khadri, Raveendra D. Totad and Asma Begaum Biradar. 2017. Profile of Opportunistic Infections and CD4 Count in HIV/AIDS Patients in and Around Vijayapur, Karnataka. Int.J.Curr.Microbiol.App.Sci. 6(9): 2556-2560.

doi: https://doi.org/10.20546/ijcmas.2017.609.314 